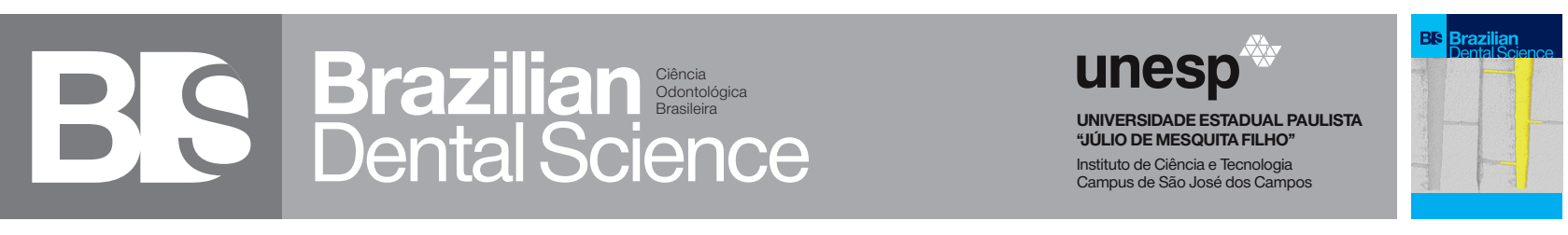

\title{
Mineral exchange between dentin pre-tretament with Dolomite powder on demineralized dentin in deciduous molars
}

\author{
Trocas minerais entre o pré-tratamento dentinário com pó de Dolomita na dentina decídua desmineralizada \\ Gisele Fernandes DIAS ${ }^{1}$, Fabiana Bucholdz Teixeira ALVES ${ }^{1}$, Daphynne Manosso SAMWAYS ${ }^{2}$, Fábio André dos SANTOS ${ }^{1}$ \\ 1 - Department of Restorative Dentistry - School of Dentistry - Ponta Grossa State University Ponta Grossa - PR - Brazil. \\ 2 - Departament of Pediatric Dentistry - School of Dentistry - Ponta Grossa State University - Ponta Grossa - PR - Brazil.
}

\begin{abstract}
Objective: The objective of this study was to evaluate differences in microhardness and mineral profiles in sound and demineralized dentin of primary molars after treatment with powdered dolomite (DMT) followed by glass ionomer cement (GIC) restoration. Material and Methods: 32 decidous molars were selected and randomly assigned to four groups according to dentin pretreatment and dentin condition. Class I cavities were prepared in 32 decidous molars, equally divided into groups G1 (sound dentin) and G2 (demineralized dentin). This in vitro study examined the mechanical and chemical exchange under two conditions: sound and demineralized dentin ( $\mathrm{pH}$ cycling) to simulate the mineral loss occurs for the caries lesion. The 16-tooth (G1DMT, G2DMT) received first topical application of DMT and restoration of high viscosity GIC. The 16 teeth assigned to the groups (G1 and G2) were restored only with GIC. The specimens were sliced and prepared for Knoop hardness test (KHN), Micro Raman and FEG microhardness analysis. Results: The statiscal analysis used ANOVA and Bonferroni post-test at a significance level of $5 \%$. Micro Raman and FEG data were qualitatively described. Conclusion: DMT associated with GIC resulted incresead microhardness values of the demineralized dentin substrate, with positive repercussions of the chemical-mechanical properties of the dentin demineralized.
\end{abstract}

\section{KEYWORDS}

Dental caries; Dentin; Glass ionomer cement.

\section{RESUMO}

Objetivos: O objetivo deste estudo foi avaliar alterações minerais e repercussões em propriedades mecânicas em dentina hígida e desmineralizada de molares deciduous após tratamento com dolomita (DMT) em pó, seguida de Cimento de Ionômero de Vidro (CIV). Material e Métodos: Foram preparadas cavidades classe I em 32 molares decíduos, divididos em G1 (dentina hígida) e G2 (dentina desmineralizada). A cavidade de classe I foi dividida em dois sítios, um deles foi isolado com esmalte (porção mesial) para obter uma área de sem-contato (área controle: SC) e contato (área teste: C) com DMT. As cavidades de 16 dentes (G1DMT, G2DMT) receberam aplicação do DMT e restauração de CIV. Os 16 dentes destinados aos grupos (G1 e G2) foram restaurados com CIV. Os espécimes foram fatiados e preparados para análise de microdureza Knoop, Micro Raman e FEG. As variáveis dentina (hígida e desmineralizada), tratamento (sem e com DMT) e interação (dentina e tratamento) foram analisadas com o teste ANOVA fatorial e pós-teste de Bonferroni nível de significância de $5 \%(\alpha=0,05)$. Resultados: Os resultados mostraram nas áreas SC: diferença significativa foi encontrada ao fator dentina ( $p=0,0001)$. Não foram encontradas diferenças significativas na interação dentina e tratamento $(\mathrm{p}=0,238)$. $\mathrm{Na}$ área $\mathrm{C}$ : não houve diferença significativa em relação à dentina $(p=0,391)$. No entanto, houve diferença significativa na interação dentina e tratamento $(p=0,001)$. Conclusão: As trocas minerais entre DMT, CIV e dentina desmineralizada podem induzir mudanças das propriedades mecânicas do substrato dentinário ao promover a incorporação de íons minerais. A aplicação direta da DMT no tecido desmineralizado alterou as propriedades químico-mecânica sem a necessidade de associar o CIV.

\section{PALAVRAS-CHAVE}

Cárie; Dentina; Dente decíduo; Cimentos de Ionômeros de vidro. 


\section{INTRODUCTION}

$\mathrm{T}$ he current approach to a clinical situation of deep caries in deciduous teeth includes partial removal of carious tissue, which consists of removal of non-remineralizable carious tissue [1]. The deeper layer of the cavity preparation (bottom wall) should not be removed in asymptomatic teeth to avoid pulpal exposure $[2,3]$. Thus, in the clinical situation described, the therapeutic procedure of indirect pulp capping (IPC) is used where. The superficial layer of infected dentin, extensive demineralization, degradation of collagen fibers and infected dentin is removed [4]. Indication of the technique should include signs of endodontic infection, including: spontaneous pain, mobility in the periodontal tissues, presence of radiopacity in the furcation zone or peri-apex pathological root resorptions [4]. The IPC technique has been used successfully for deciduous dentition, where clinical evaluations, radiographic and microbiological aspects of this treatment employed in carious lesions close to the pulp have been made with very positive results.

The use of glass ionomer cements (GIC) is indicated for IPC due to its capacity to adhere to the dentin structure, similar coefficient of thermal expansion as dentin and modulus of elasticity similar to the tooth structure, besides the fluoride release and biocompatibility $[5,6,7]$. Another peculiar characteristic of GIC consists in the syneresis and inhbibition after its manipulation, which can result in hydrolytic degradation and consequently compromise the mechanical properties of the restoration $[8,9,10]$. For this reason, the search for materials that allow high rates of success for conservative pulp treatment is constant. When considering the repair process as a physiological process, the clinical challenge lies in the attempt to improve the condition of the carious dentin substrate. It means that the demineralized substrate receives a restorative material that can promote exchange mineral and should be considered for acute and deep carious lesion control.
The research for a biomaterial capable of improving the chemical and mechanical properties of the demineralized dental substrate from the chemical interaction with dentin was proposed in this study by including dolomite (DMT) to increase the amount of available calcium in the attempt to alkalize the demineralized and sealed in the technique of atraumatic restoration. Dolimiteis a common mineralmineral composed of double carbonate of calcium and magnesium (CaMg (CO3) 2), a rock discovered by French geologist Deodat Dolmieu in the Tyrolean Alps (1750-1801) $[11,12]$. In the chemical reaction it precipitates in the form of $\mathrm{Ca}$ and $\mathrm{Mg}$ carbonates, which can promote crystallization through a sedimentation mechanism of DMT (12). Its white color and very fine texture favors the absorption and fixation of calcium in the bones, which the magnesium present in DMT activates more than 326 enzymatic systems of the human body [11,12]. DMT presents antimicrobial activity, according to some studies $(10,12)$. Since the deposition of DMT crystals can undergo maturation and recrystallization together with increased crystallinity, which can produce a highly chemically ordered material $[12,13]$. Moreover, the $\mathrm{Mg} / \mathrm{Ca}$ rates increase carbonate precipitation [12]. It is known that at balanced concentrations of fluoride (greater than 0.05 $\mathrm{mM}$ ), from the sorption process, precipitation occurs in calcium fluoride through the release of $\mathrm{Ca}$ ions from $\mathrm{CaO}$ [14]. The changes in the concentrations and $\mathrm{pH}$ of the $\mathrm{F}^{-1}, \mathrm{Mg}^{+2}$ and $\mathrm{Ca}^{+2}$ ions present in DMT decrease rapidly and remain in equilibrium after $24 \mathrm{~h}[13,14]$. What is known through solid waste EDS models is that F sorption promotes the formation of $\mathrm{CaF}_{2}$. So that DMT can be a powerful adsorbent of fluorides. However, there are no clinical studies validating such effects (10-14), nor any applications in dentistry.

The study of the chemical exchanges between bioactive materials and dental tissues has been the subject of much research, as well as the changes in the physicochemical properties of the dental structures involved [15]. Therefore, 
this in vitro study aimed to evaluate the chemical exchange of DMT applied prior to restoration of GIC, in deep dentin demineralized deciduous and repercussions on the mechanical- chemical properties of the dental tissues involved.

\section{MATERIAL \& METHODS}

This research was approved by the Ethics in Research Committee, protocol \# 1.565.693 .

\section{Sample}

The sample consisted of 40 deciduous molars without any crown defects or carious lesion. Eight teeth were lost during preparation of specimens. The sample consisted of 32 primary molars without any crown defects or carious lesions. The remaining root portions were removed using a high-speed diamond bur (2121 KG Sorensen ${ }^{\circledR}$, Cotia, SP, Brazil), and the teeth were stored in distilled water at $37^{\circ} \mathrm{C}$ temperature to avoid dehydration until cavity preparation.

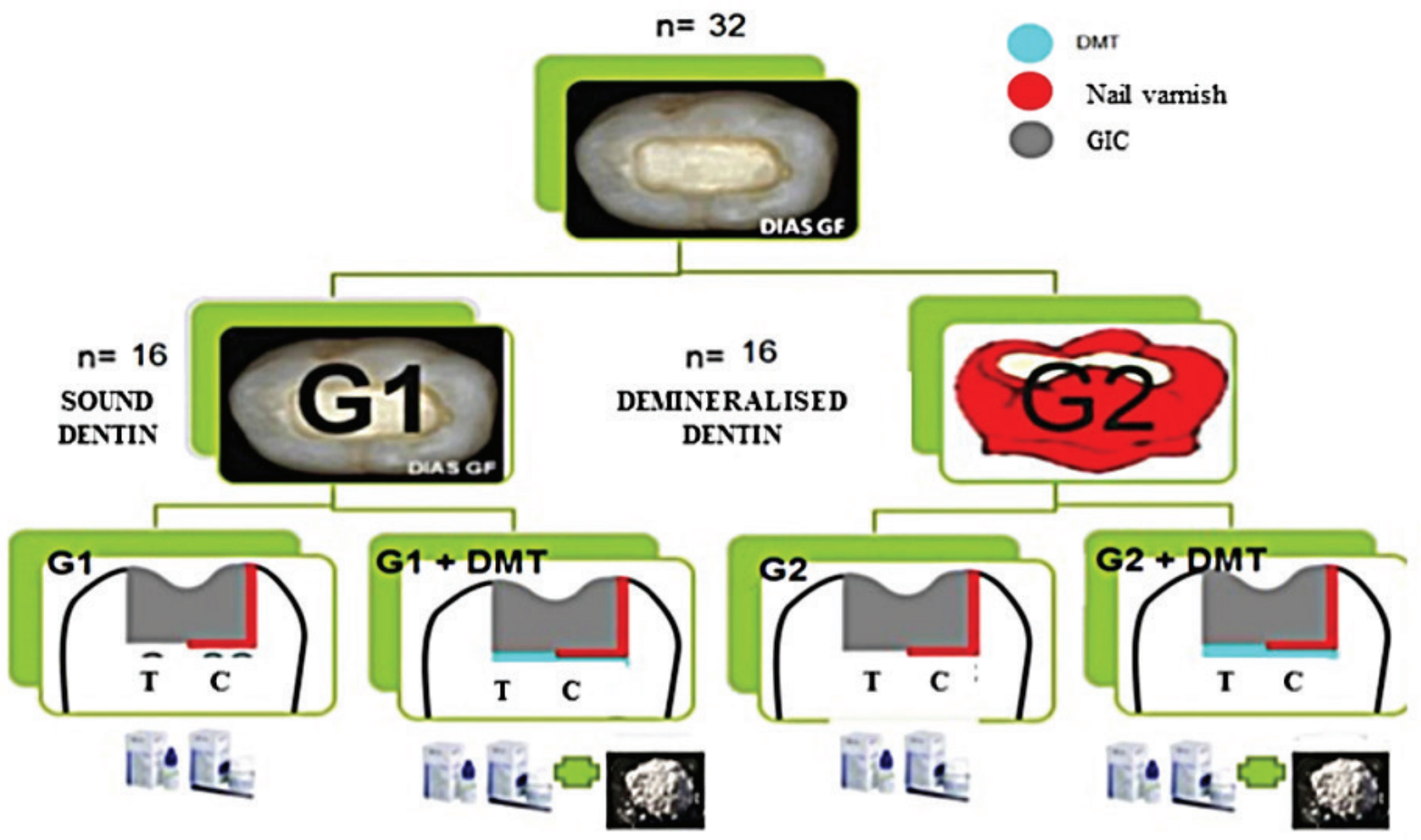

Figure 1 - Teeth in two dentin conditions: sound/demineralised (G1, G2) and with topical application of DMT powder before restoration ( G1 DMT, G2 DMT). Red nail varnish layer has been applied to avoid direct contact of GIC with the half of the dentin control area (C) and test area (T). 


\section{Preparation of the class I cavities}

A drilling apparatus (El Quip ®, São Carlos, SP, Brazil) was used in the preparation of the cavities, which were standardized (depth $=2 \mathrm{~mm}$, length $=6 \mathrm{~mm}$ and wide $=4 \mathrm{~mm}$ ). The size of the cavities was checked with a caliper (Digimess $®$, São Paulo, SP, Brazil). The cavity size was based on a deep cavity, characteristic of deep carious lesions. Deep cavities are considered with more than 0,5 $\mathrm{mm}$ and less than $1 \mathrm{~mm}$ remanescent structure between floor and pulp. The preparation of the cavities was started in the center of the occlusal surface of each primary molar. Tungsten carbide burs \#8 with an initial depth of $1.5 \mathrm{~mm}$ were used to reach the final size set at $2 \mathrm{~mm}$ with a diamond high rotation \#3131, under continuous cooling. After 8 cavities, drills were replaced by new ones. To complete this step, the teeth were taken to the ultrasonic tank (Cristófoli Biosafety ${ }^{\circledR}$, Campo Mourão, PR, Brazil) for 280s to remove debris from the cavity preparation. Visual examination of specimens with a stereoscopic magnifying glass (10X) allowed verification of whether the pulp chamber was exposed by cavity preparation. If so, the tooth was discarded.

\section{Procedures for $\mathrm{pH}$ cycling}

The $\mathrm{pH}$ cycling is appropriate to simulate a substrate that resembles affect dentin layer. The teeth in G2 $(n=16)$ were subjected to dentin demineralization to simulate carious lesions using the method of $\mathrm{pH}$ cycling 11 . To protect the external area of dental crowns, two layers of nail varnish (Colorama ${ }^{\circledR}$, Rio de Janeiro, RJ, Brazil) were applied, avoiding contact with the internal walls of the cavity.

Artificial dentine carious lesion were created by a $\mathrm{pH}$ cycle procedure, each specimen was immersed for $8 \mathrm{~h}$ in demineralizing solution and for $16 \mathrm{~h}$ in remineralizing solution. The volume of the demineralizing and remineralizing solution was $10 \mathrm{ml}$ for each tooth in every cycle. This cycle was repeated for 14 consecutive days at room temperature without stirring. The solutions used in $\mathrm{pH}$ cycling were manipulated in the Pharmaceutical Science Lab at UEPG. The formulations (16) were as follows: demineralizing solution ( $\mathrm{pH}$ 4.8) with $2.2 \mathrm{mM}$ calcium chloride $\left(\mathrm{CaCl}_{2}\right)$; $2.2 \mathrm{mM}$ phosphate Sodium $\left(\mathrm{Na}_{2} \mathrm{PO}_{4}\right)$ and 50 $\mathrm{mM}$ acetic acid; and remineralizing solution (pH 7.0): $1.5 \mathrm{mM}$ calcium chloride $\left(\mathrm{CaCl}_{2}\right), 0.9$ $\mathrm{mM}$ phosphate Sodium $\left(\mathrm{Na}_{2} \mathrm{PO}_{4}\right)$ and $0.15 \mathrm{mM}$ potassium chloride $(\mathrm{KCl})$.

\section{Application of DMT powder}

Before the restorative procedures, all the cavities received a layer of nail varnish on the mesial side cavity. This research design stipulated the division of the cavity into two sites: control area (C) and test area (T). This was done to guarantee that the GIC would not be in contact with the dentin, as well as to make sure that the DMT would be the only chemical element in contact with the dentin.

Application of DMT powder was carried out only for G1DMT and G2DMT (Figure 1) in the cavity bottom. For these groups, after the application of the polyacrylic acid conditioner Ketac conditioner (3M ESPE, St. Paul, MN, USA) before the restoration, a pre-treatment with DMT was applied on the dentin for $1 \mathrm{~min}$ with the aid of a GIC dispenser, and the volume to each cavity was standardized. It was taken to cavity fund with the aid of a measuring spoon of GIC. After it was not withdrawn DMT poder.

\section{Restorative Procedures}

All cavities were filled with high-viscosity GIC (Ketac Molar Easymix ${ }^{\circledR}, 3 M$ ESPE, St. Paul, MN, USA). The cavities were treated with polyacrylic acid conditioner Ketac conditioner (3M ESPE, St. Paul, MN, USA) for 10s, washed with air/water spray for 20s, dried with a gentle stream of dry compressed air and immediately filled with the GIC. The GIC was dosed at a ratio of 1:1 (powder and liquid), and manipulated on the block by mixing with a plastic spatula (Duflex ${ }^{\circledR}$, Rio de Janeiro, RJ, Brazil). The mixture was inserted with an applicator syringe (Precision Maquira ${ }^{\circledR}$, Maringa, PR, Brazil) until the cavity was filled. The glass ionomer was allowed to set for $3 \mathrm{~min}$, in accordance with the instructions of the manufacturer. Following restoration, the teeth were stored for $24 \mathrm{~h}$ at $37{ }^{\circ} \mathrm{C}$. 


\section{Preparation of specimens for tests}

The teeth were fixed in a cutting machine (Isomet @ 1000 Precision Saw Buehler, Lake Bluff, IL, USA) and were sectioned vertically with a diamond disk (1.3 mm Precision Saw, Lake Bluff IL ®, USA) at $300 \mathrm{rpm}$ to obtain slices $(\mathrm{n}=3)$ with approximately $1.1 \mathrm{~mm}$ thickness. Two slices were mounted in the center of PVC (Tiger $®$, Joinville, SC, Brazil) cylinders (12 x $20 \mathrm{~mm}$ ), which were attached with doublesided tape (3M®, SUMARE, SP, Brazil) on a glass plate. The cylinders were filled with colorless acrylic resin (JET $®$, Clear Field, SP, Brazil). The embedded slices were polished with a sequence of silicon carbide sandpapers (3M $®$ Brazil, Sumaré, SP, Brazil) with water irrigation in a semi-automatic polisher (Arotec, Cotia, SP, Brasil). Final polishing was performed with $1 / 1 / 4 \mu \mathrm{m}$ diamond paste (Arotec $\AA$, Cotia, $\mathrm{SP}$, Brasil). For removal of waste, the specimens were washed for $12 \mathrm{~min}$ in an ultrasonic bath. Finally, they were stored at $37^{\circ} \mathrm{C}$ for $24 \mathrm{~h}$ in a $100 \%$ humidity environment.

\section{Microhardness Test}

The microhardness analysis was performed on a microhardness apparatus (Shimadzu $\AA$, Kyoto, Japan) with a Knoop indenter. Loads were $25 \mathrm{~g}$ for sound dentin and $10 \mathrm{~g}$ for demineralized dentin applying during $30 \mathrm{~s}$ [16].

The loads were applied on the specimens $50 \mu \mathrm{m}$ below the cavity floor, wich characterized a deep cavity. Three different measures were made at $100 \mu \mathrm{m}$ distance from each other at the same depth [16]. The mean between these three measures was considered the microhardness value of the specimen.

\section{Scanning eléctron microscopic evaluation and chemical mapping}

For evaluation in FEG, five slices of each group were separated. The specimens previously selected were glued on metal stubs with a cyanoacrylate (Pegamil bondgel ultra forte, São José, SC, Brazil) with the aid of a microbrush. Afterwards, the specimens were stored in an oven for $48 \mathrm{~h}$ for drying, prior to reading.
The reading was performed at $50 \mu \mathrm{m}$ depth of the cavity base with magnification of $5000 x$. The reading regions were divided into $\mathrm{C}$ and $\mathrm{T}$ areas of the restorative material with dentin, a limit imposed by the presence of red enamel on cavity.

\section{Micro-Raman Spectroscopy}

The same specimens used for the microhardness test were subjected to analysis of mineral composition through micro-Raman spectroscopy (Bruker Optik GmbH, Ettlingen, Baden-Württemberg, Germany). The apparatus was calibrated first to zero and then for the values of coefficients using a silicone sample.

The test included the following parameters: a neon laser with $532 \mathrm{~nm}$ wavelength and 20 $\mathrm{mW}$, a spatial resolution of $\approx 3 \mathrm{mM}$, spectral resolution of $\approx 5 \mathrm{~cm}^{-1}, 20 \mathrm{~s}$ accumulation time and 5 co-additions at $20 \mathrm{X}$ magnification (Olympus UK, London, UK) for a laser $\approx 1 \mathrm{~mm}$ in diameter. Readings were taken in a spectral range $300-1800 \mathrm{~cm}^{-1}$. The spectra were obtained from the dentin just below the tooth-restoration interface in a random place with a three-point mapping analysis: $0,0.45$ and $90 \mu \mathrm{m}$ in depth.

The micro-Raman spectroscopy detected the chemical content of the dentin through the vibrational molecular characteristics of energy. The representative spectra of calcium phosphate (corresponding to $960 \mathrm{~cm}^{-1}$ ) were identified, and peaks of different vibrational modes of the phosphate group $\left(591 \mathrm{~cm}^{-1}, 430 \mathrm{~cm}^{-1}\right)$, carbonate $\left(1070 \mathrm{~cm}^{-1}\right)$, collagen $\left(1270-1453 \mathrm{~cm}^{-1}\right)$ and peak and peak DMT were represented by the interval of $1080 \mathrm{~cm}^{-1}$ present in the samples.

\section{Statistical Analysis}

The distribution of normality was verified with D'Agostino \& Pearson and Shapiro Wilks tests; homogeneity of variances was tested with Levene's test. The hardness data were analyzed using ANOVA 2 criteria considering the factors dentin (sound and demineralized), treatment (with and without DMT) and the dentintreatment interaction. The level of significance used was 5\%. The data micro-Raman spectra e 
FEG were analyzed qualitatively by the groups. The statistical program GraphPad Prism version 5 for Windows (GraphPad Software, San Diego California, USA) was used for data analysis.

\section{RESULTS}

There was a significant difference in hardness values in DMT treatment in the $\mathrm{T}$ and $C$ areas ( $<<0.001)$; (Figure 2). There was a significant difference for the dentin factor in $\mathrm{C}(\mathrm{p}<0.0001)$. The interaction dentine $\mathrm{X}$ treatment did not effect significant changes in the hardness of dentin, and there was no significance difference in the control area $\mathrm{C}(\mathrm{p}=$ $0.238)$ or the test area $T(p=0.391)$. The data obtained in the Micro-Raman by spectroscopy are shown in Figure 3. The range of the spectral region involved $\left(275-1700 \mathrm{~cm}^{-1}\right)$ was identified in all groups, with the highest intensity of the indicated peaks listed below: 1- $960 \mathrm{~cm}^{-1}$ (PO${ }^{3}$ ), $591 \mathrm{~cm}^{-1}$ and $430 \mathrm{~cm}^{-1}$ (peaks of different vibrational modes of the phosphate group) representative of calcium hydroxyapatite, 2 $-1070 \mathrm{~cm}^{-1}$ (carbonate), representative of the product formed by the CIV within the collagen fibers and $3-1080 \mathrm{~cm}^{-1}$ Peak of DMT found in G1 DMT and G2 DMT groups. In the Micro-
Raman spectrum of the G1 DMT C group, within the range of the spectral region involved (275$1700 \mathrm{~cm}^{-1}$ ), the spectra of the phosphate group at absorbance in the range of $0-1500$ were characterized. When analyzing the three depths $(0,45$ and $90 \mu \mathrm{m})$ relative to the cavity base, the highest absorbance peak was found in the cavity base. In the micro-Raman spectrum of group G1 GMT NC, within the range of the involved region $\left(275-1700 \mathrm{~cm}^{-1}\right)$ in the absorbance range $(0-1500)$ there was difference in the analyzes of the three depths, being the level of higher absorbance found in the cavity base (Figure 4). The DMT peak was not identified. In the micro-Raman spectrum of the G2 DMT C group within the range of the spectral region involved $\left(275-1700 \mathrm{~cm}^{-1}\right)$, three spectras were characterized at absorbance in the range of $0-1300$. The phosphate peak was evidenced in two intervals, being $960 \mathrm{~cm}^{-1}$ and $591 \mathrm{~cm}^{-1}$. The highest peak of phosphate was found in the cavity base. DMT was identified at peak $1080 \mathrm{~cm}^{-1}$. In the micro-Raman spectrum of the G2 DMT SC group, within the range of the involved region $\left(275-1700 \mathrm{~cm}^{-1}\right)$ the depth $90 \mu \mathrm{m}$ obtained the highest peak at the $960 \mathrm{~cm}^{-1}$ phosphate peak.

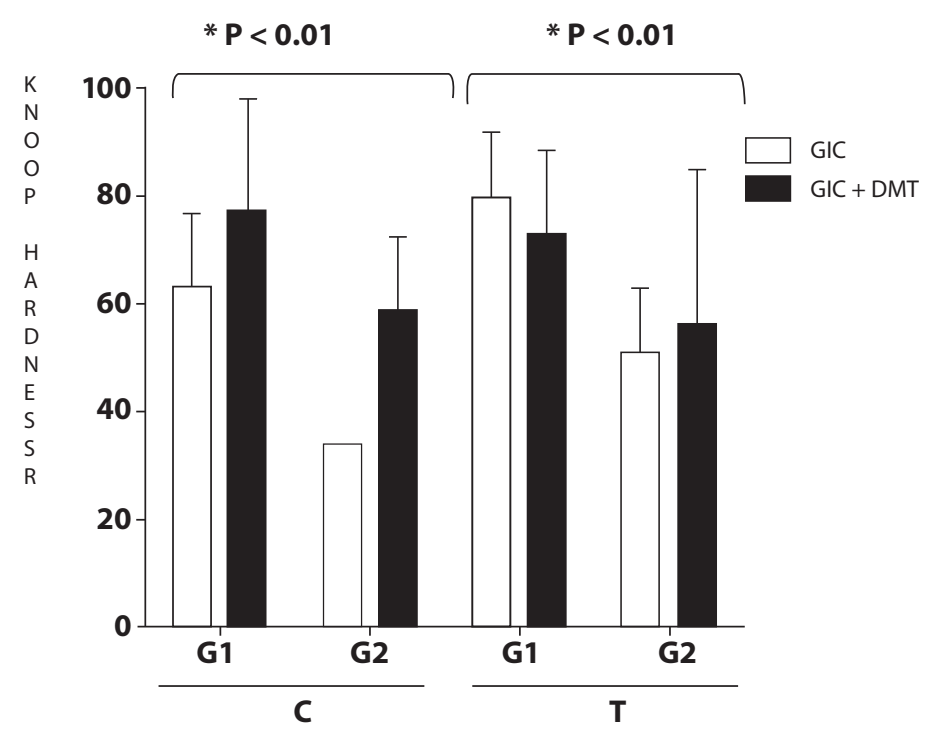

Figure 2 - Mean and standard deviation of Knoop hardness values. $\left(^{*}\right)$ Significant differences for the factor dentin in areas without contact (control area) and contact (test area). Dentin factor was no significant difference in the area $\mathrm{C}(\mathrm{p}<0.01)$ and no significant difference in the T $(p=0.391)$. The interaction dentine $x$ treatment there was no significant difference according to the $C(p=0.232)$ and the $T(p=0.391)$. Anova 2 criteria. 

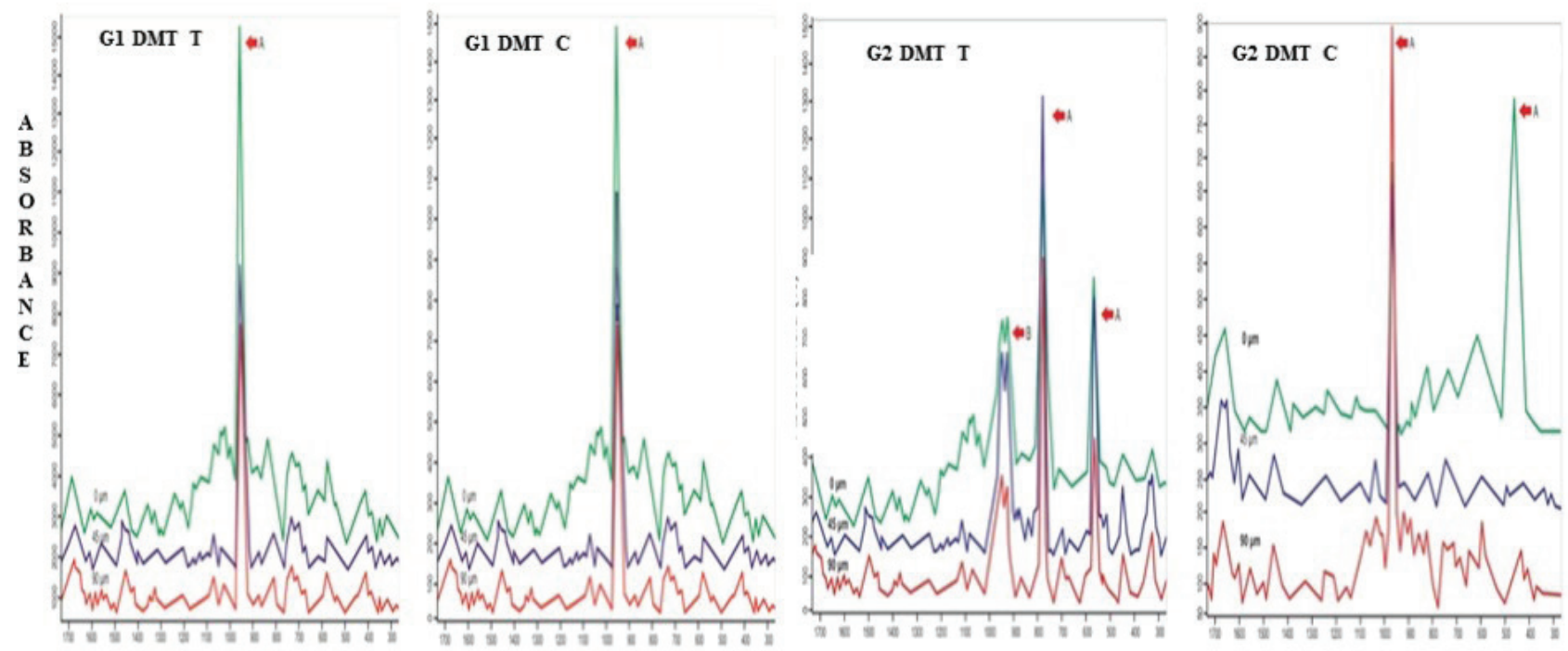

Figure 3 - Spectra obtained from the analysis of the dentin composition by spectroscopy micro-Raman DMT group. G1DMT T (sound dentin treated with GIC + DMT), G1 DMT C (sound dentin treated with DMT, without contact with GIC). G2 DMT T (demineralized dentin treated with GIC + DMT), G2 DMT C (demineralized dentin with DMT, without contact with GIC. Higher absorbance found in the cavity base in both groups (C, NC). The arrows indicate: (A) Phosphate; (B) Dolomite.
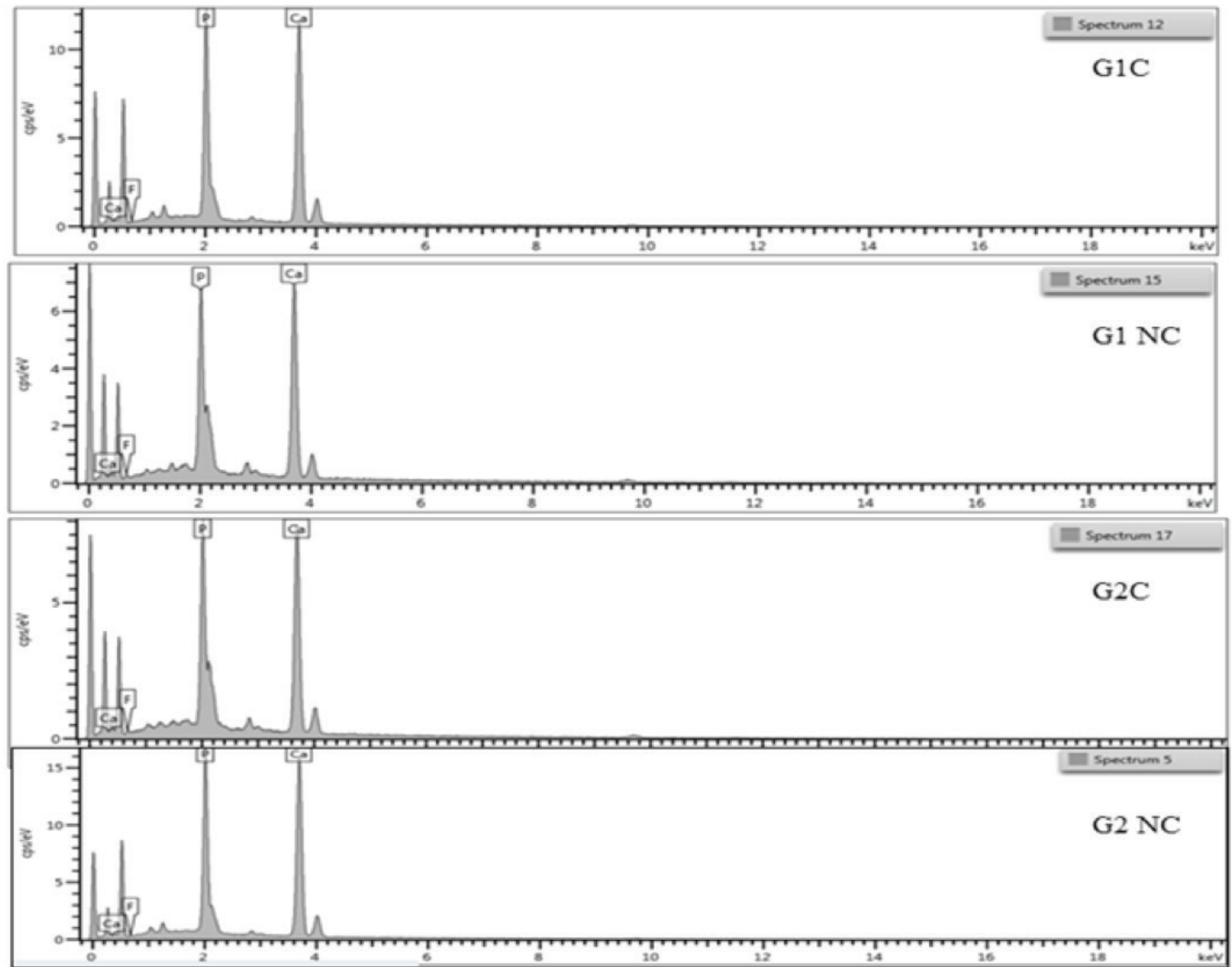

Figure 4 - Representative images of EDS from cavity floor. (G1T) Primary teeth baseline; (G1C) primary teeth no contact baseline; (G2 T) primary teeth demineralised after tretment with DMT and GIC; (G2C) primary teeth demineralised after wear with GIC; High ion mineral data picos $\mathrm{Ca}$ ( calcium), $\mathrm{P}$ (phosphate) and $\mathrm{F}$ (fluoride) 


\section{DISCUSSION}

The demineralized dentin obtained by artificial caries lesion created by the modified $\mathrm{pH}$ cycling method (16) attempts to simulate the mineral saturation dynamics associated with the $\mathrm{pH}$ variation of the natural caries formation process. This laboratory method is considered adequate to evaluate the loss and mineral gain of the dental substrate. Some studies have evaluated ion exchange values between dentin and restorative material through artificial carious lesions and have concluded that the in vitro method allows detailed studies of the interactions between restorative material and demineralised dentin $[15,16]$.

The mean values, according to a study employed by Marquezan et al. [16], in the test of hardness in the deciduous integral dentin vary from 50 to $70 \mathrm{KHN}$ and the average values in the demineralized dentin are below $50 \mathrm{KHN}$, generally around $30 \mathrm{KHN}$. In this research, the demineralized dentin (G2 DMT) was the most reactive substrate, since there was a higher percentage increase of ions, both in $\mathrm{C}$ and $\mathrm{T}$, which suggests that DMT is a direct depositor of minerals that can contribute to the increase of the chemical properties of the dentin substrate. The method used in our study produced artificial caries lesion, the mineral loss result from this method translate in a significant reduction in Knoop hardness, wich reached of half of the values from sound dentin $[17,18]$.

Complete removal of carious tissue compared to partial removal produces similar results in terms of dental caries progression and restoration longevity. Although there are high rates of clinical success reported in many studies, the uncertainty still lies in the maintenance of the affected dentin. However, partial removal of carious tissue has been commonly employed in pediatric dentistry [4$6]$. The mecanical removal of carious tissue and its replacement by restorative materials can contribute to the increased success of pulpar treatment, in which the base resides in partial caries removal and contributes in the treatment of deep cavities without signs of pulpal degeneration $[1,2]$. Regarding the liner products, calcium hydroxide is a successful material, consisting of a sensitive method for deep cavity treatment in deciduous teeth due to the stimulation of the production of reactive dentin [19]. Studies have shown that the clinical effectiveness of substances in residual dentin after partial removal of caries $[1,3,4,10,18,19]$ promoves a longevity of restoration. Dentistry has moved from the surgical approach of caries lesions to the philosophical of minimal intervention to control and manage caries lesions, by preventing the cariogenic process from developing into symptoms. DMT is composed of calcium, which results in high values of this ion release [20-22]. Another factor of importance is that studies have revealed that the composition of dentin, enamel and cement concentrate high values of magnesium, which also present in dolomite could affect in the metabolism of mineralization, by increasing the magnesium gradient. Furthermore, it reveals that, indirectly, magnesium would influence metabolismo of mineralization by enzymatic factors, directly due to effects of the crystallization process in the inorganic mineral phase [13,20-22]. DMT would have action of a magnesium and calcium 'repository', in which it could cause an increase of calcium / phosphate ions in the receptor substrate. In studies, DMT was chosen as a repair material because of its composition rich in calcium and magnesium, important minerals in the constitution of the inorganic bone matrix [11,20-22]. It suggests the stimulation of osteogenic action by playing a supporting role in the formation of new mineral complexes in contact with dentin. And data on the surface chemical composition of DMT, considered effective action of $\mathrm{F}$ adsorption and formation of CaF2 $[9,12,14]$. It coincides with the high values of calcium, phosphorous and fluoride minerals performed in this study through FEG as well as significant differences in the hardness tests in the region where DMT had isolated action of the GIC. Regarding the results of the Micro-Raman, the demineralized dentin revealed the presence of dolomite, proving its stability and alkalinization of the 
medium while promoting high indexes also of phosphate. In this way, more studies could be done to analyze the possibility of using DMT as a constituent of dental material, since this study revealed the effects of surface treatment of carious dentin.

The pre-treatment of DMT to dentine prior to the application of GIC demonstrated mineral gain ( $\mathrm{Ca}$ and $\mathrm{P}$ ) with repercussion on the mechanical properties of the demineralized dentin. Therefore, the shortage of DMT information related to the field of dental material leads to limited knowledge of mechanisms of remineralization of caries lesion through the use of DMT. The information present in the literature is limited to the chemical and synthetic part of DMT, so that the reactivity should be better explored in relation to bioactivity, mainly due to the significant difference found in the demineralized dentin in direct contact with DMT. The present study used hardness data that provided data to elucidate the mechanical properties of deciduous teeth, together with the transformations of dentin chemical composition through FEG and Micro-Raman.

The data can predict the behavioral model of the dentin, DMT and GIC interaction. This research showed that mechanical properties of deciduous teeth at microscopic levels are highly dependent on the chemical and mechanical microstructural characteristics of the materials used in direct contact with the demineralized structure, capable of altering mineral composition and affect the improvement of the mechanical properties of the structures.

\section{CONCLUSION}

From the results of this study, DMT could be an alternative dental material for deep carious lesions in deciduous teeth, due to changes in the chemical and mechanical properties of the demineralized deciduous dentin. The increase in dentin hardness and changes in mineral contentes were due to ion exchange from DMT to dentin. However, it can not be considered a determinant factor for the success of restorative procedures, due to the incipient knowledge of DMT in dental products. More studies on the effect of DMT over demineralized dentin shouldbe performed.

\section{REFERENCES}

1. Dalpian DM, Casagrande L, Franzon R, Dutra GMC, Araujo FB. Dentin microhardness of primary teeth undergoing partial carious removal. JClin Pediatr Dent. 2012;36(4):363-7.

2. American Academy of Pediatric Dentistry. Guideline on pulp therapy for primary and young permanent teeth. Pediatr Dent. 2009;30:170-4.

3. Casagrande L,Bento LW, Rerin SO, Lucas Ede R, Dalpian DM, de Araujo FB. In vivo outcomes of indirect pulp treatment using a selfetching primer versus calcium hydroxide over the demineralized dentin in primary molars. J Clin Pediatr Dent. 2008;33:131-5.

4. Casagrande L, Dalpian DM, Bento LW, Garcia-Godoy F, Araujo FB. Indirect pulp treatment in primary teeth after long-term function. Am J Dent. 2010;23:34-8.

5. Duque C, Negrini TC, Sacono NT,Spolidorio DM, de Souza Costa CA, Hebling J. Clinical and microbiological performance of resinmodified glass-ionomer liners after incomplete dentine caries removal. Clin Oral Investig. 2009;13:465-71.

6. Calvo AFB, Kicuti A, Tedesco TL, Braga MM, Raggio DP.Evaluation of the relationship between the cost and properties of glass ionomer cements indicated for atraumatic retorative treatment. Braz Oral Res. 2016;30. pii: S1806-83242016000100201.

7. Bonifácio CC, Kleverlaan CJ, Raggio DP, Werner A, Carvalho RC, Amerongen WE. Physical-mechanical properties of glass ionomer cements indicated for atraumatic restorative treatment. Aust Dent J. 2009;54(3):233-7.

8. Paschoal MA, Gurgel CV, Rios D, Magalhaes AC, Buzalaf MA, Machado MA. Fluoride reliase profile of a nanofileed resin-modified glass ionomer cement. BrazDentJ. 2011;22(4):275-9.

9. Hattab FN, Amin WM. Fluoride release from glass ionomer restorative materials and the effects of surface coating. Biomaterials. 2001;22(12):1449-58.

10. Gugliemi CA, Raggio DP, TaKeuti ML, Camargo LB, Imparato JC. Fluoride release and uptake of glass ionomer cements indicated for atraumatic restorative tratmente. Pesq Bras Oontoped Clin Integr.2011;11(4):561-5.

11. Slomski G, Odle T."Dolomite."Gale Encyclopedia of Alternative Medicine.2005.

12. Zhang F, Xu H, Konishi H, Kemp JM, Roden EE, Shen Z. Dissolved sulfidecatalyzed precipitation of disordered dolomite: implications for the formation mechanism of sedimentar dolomite. Geochimica et Cosmochimica Acta. 2012;97):148-65.

13. Deng S, Dong h, Lv G, Jiang H, Yu B and Bischoff ME. Microbial dolomite precipitation using sulfate reducing and halophillic bactéria: Resultos from Qinghai Lake.Chem Geol 2010;(278): 151-9.

14. Sasakik. Yoshida m, Ahmad Bshir,Fukumoto N, Hirajima T. Sorption of fluoride on partially calcined dolomite. Phsyicochem Eng Aspects. 2013;435:56-62.

15. Ngo HC, Mount G,Mcintyre JM, Do L. An in vitro model for the study of chemical exchange between glass ionomer restorations and partially demineralized dentin using a minimally invasive restorative technique.JDent. 2011;39(2):201-6.

16. Marquezan M, Corrêa FN, Sanabe ME, Rodrigues Filho LE, Hebling J, GuedesPinto AC. Artificial methods of dentine caries induction: a hardness and morphological comparative study. Arch Oral Biol. 2009 Dec;54(12):1111-7.

17. Zavgorodniy AV, Rohanizadeh R, Swain MV.Ultrastructure of dentine carious lesions. Arch Oral Biol. 2008 Feb;53(2):124-32. 
18. Lula ECO, Monteiro Neto V, AlvesCMC, Ribeiro CCC. Microbiological analysis after complete or partical removal of carious dentin in primary teeth:a randomized clinical trial. Caries Res. 2009;43:354-8

19. Falster CA, Araujo FB, Straffon LH, Nor JE. Indirect pulp treatment: in vivo outcomes of na adhesive resin system vs calcium hydroxide for protection of the dentin-pulp complex. Pediatr Dent. 2002;24:241-8.

20. Camilleri, Wang D, Wallace AF, De yoreo KK, Dove PM. Carboxylated molecules regulate magnesium contente amorphous calcium carbonates during calcification. Proc Nati Acad Sci USA. 2009;106(51):21511-6.
21. Duarte MA, Demarchi AC, Yamashita JC, Kuga MC, Fraga Sde C. Ph and calcium ion releas of 2 root-end filling materials. Oral Surg Oral Med Pathol Oral Radio Endo 2003:95(3):343-7.

22. Kenward PA, Goldstein RH, Gonzalez LA, Roberts JA. Precipitation of low temperature dolomite fronm na anaerobic microbial consortium: the role of methanogenic Archae. Geobiology.2009;7(5):556-65.

\section{Gisele Fernandes Dias}

\section{(Corresponding address)}

School of Dentistry - Ponta Grossa State University

General Carlos Cavalcanti Avenue, \#4748 CEP 84030-900,

Ponta Grossa - PR - Brazil.

e-mail: giodonto@hotmail.com 